\title{
Development Of A Variation Model Of Long-Jump Learning In Sport Coach Students In 2018
}

\author{
Yan Indra Siregar ${ }^{1}$ \\ $\left\{\right.$ yanindrasiregar@gmail.com $\left.{ }^{1}\right\}$ \\ Faculty of Sport Science, Medan State University, Medan ${ }^{1}$
}

\begin{abstract}
This study aims to develop a model of 2018 long jump training. Contributing knowledge and thoughts that can be used as a guiding guidance for lectures. Improve techniques in playing with different learning methods so that learning is not boring for students. The population in this study were 30 students of Sports Coaching Education. The model that has been made in advance is validated by 4 experts in the field of sports, namely 2 people are Long Jump trainers and 2 people are sports academics. The small group test involved 15 students and a large group test involving 30 FIK UNIMED PKO students.With the various models of learning development, it is also expected to provide good preparation for students as future educators. By giving a lot of models of learning model development in learning, it is expected that students can be applied when they become teaching staff, so that graduates from Sports Coaching Education can provide different colors when they are in the work environment, by mastering many learning models, PKO alumni teaching staff will be able to increase the learning interest of their future students.
\end{abstract}

Keywords: Development of Learning Models Long jump training, athletics.

\section{Introduction}

Athletics is the parent of all sports. However, along with the rapid growth of sports numbers in athletic games even very minimal demand by the general public and Unimed FIK students, especially PKO study programs. Athletic courses are learning that must be followed by all PKO students, but on the way, students who study this sport tend to be less than the other dominant game sports.

Long jump numbers are one of the lessons in athletics. The treatment that is often carried out by PKO students in following this learning is relatively mediocre.. Simplicity in doing this long jump sometimes causes boredom and without challenges. This lack of variation in learning makes the level of saturation even higher in its implementation. In following student learning tends to be ordinary and only tries to make a leap in accordance with the techniques he mastered and pursue the results of leaps to the furthest in accordance with his abilities. Looking at this phenomenon, the researcher who is an athletic subject lecturer tries to increase the enthusiasm of student learning by giving six variations of training in increasing the willingness and ability of students in performing long jumps, so that the authors decide to conduct research on Long Jump Training Variations in PKO FIK Students UNIMED Year 2018. 


\section{Literature riview}

\subsection{The nature of long jump sports}

The history of the long jump has taken place since about 13 centuries ago. This long jump sport has been around since $708 \mathrm{AD}$ when there was an Ancient Olympic race in Greece. The long jump was the only jump event that was contested at the Ancient Olympics. According to historical records, long jump sports were held by Sparta participants with a jump of 7.05 meters. In the beginning, all competitions held at the Ancient Olympics were intended as a form of war military training. The emergence of long jump sports is believed to train a warrior's dexterity in breaking through different obstacles, such as ravines or ditches. In ancient Greece, the method and technique of jumping in long jump sports was very different from the way and the current jumping technique. Leap in ancient times was made in the plural. In this event, the jumpers are only allowed to use a short run. In addition, jumpers are required to run while carrying a load in both hands, known as halteres with a weight ranging from 1 to $4.5 \mathrm{~kg}$. Physical health, spirituality also has a high personality, discipline, and sportsmanship, which in turn will form a quality human being. In the long jump style jump is one of the most popular jumping numbers in the athletic sport and is most often contested in world class competitions, including the Olympics. The long jump is a movement that jumps upwards in an effort to bring the point of weight as long as possible in the air (floating in the air) which is carried out quickly and by means of a one-foot repulsion to reach the greatest distance. The goal and goal of the long jump is to reach as far as possible as far as a landing or jumping point.

Sports has an important role in human life. Through sports can be formed a distant human there is a variety of styles or posture when flying in the air. Soegito et al (1994: 143) argues that there are three ways in a floating attitude, namely, squat style (when floating in a squatting position), lenting style (when the body is floated), the way of walking in the air (when flying the legs are swung as if walking) in the air). The simplest long jump style to be taught to beginners such as elementary school students is the long jump using squat style. Squat style long jump techniques are also the simplest compared to other styles.

According Engkos Kosasih (1985: 67) argues that the goal of a long jump is to reach a distance of leap as far as possible which has four elements in the movement, namely: prefix repulsion - the attitude of the body in the air - the attitude of the body when falling or landing. Meanwhile, according to Yusuf Adisasmita (1992: 65) argues that these four elements explained by Engkos Kosasih (1985: 65) above are a unity, namely the unbroken long jump movement sequence. Aip Syarifuddin (1992: 93) In long jumps, there are several types of styles commonly used by jumping athletes, namely: squat style, hanging style or can be called lenting style and air way style. The difference in jumping force with one another, is marked by the state of the jumping body posture while floating in the air.

\subsubsection{The nature of learning outcomes}

According to Husdarta (2013: 2) Learning outcomes are interpreted as the results of the behavior change process as a result of the interaction between individuals and their environment. Behavior as a result of the interaction between individuals and their environment. Nana sudjana (2009: 22) Suggests that learning outcomes are abilities that students have after they receive their learning experience. Someone is said to have succeeded 
in learning if the person experiences behavioral changes in three aspects, namely aspects of knowledge, attitude and skills.

\subsubsection{The nature of learning variations}

One of the basic teaching abilities that must also be mastered truly by the trainer is the skill of making variations in learning activities. These skills play a role that is no less important than other teaching skills, for the coach's efforts in teaching athletes so that the learning objectives that have been set can be achieved well. Simaremare (2007: 23) the meaning of variation is defined as the difference in variation means changing the form so that it is different from the existing or ordinary. For example "A mother varies the food menu served for the family every day" imagine we would feel bored if we eat the same food every day. In everyday life if we see, feel the same or repetitive or repeated things and we will eliminate the boredom, we try to make changes in managing our own lives.

\subsubsection{Variations in learning}

One component of teaching and learning is variation in teaching including the skills to make variations that are useful to overcome the boredom or boredom experienced by students in the learning activities and processes and also to overcome the uncomfortable condition of the room, teacher performance is not enough to cool the hearts of students and material what is taught is less attractive. Variation in teaching is an activity of the teacher in the context of the process of interaction in teaching and learning which is shown to overcome students' boredom so that, in teaching and learning situations, students always show perseverance, enthusiasm, and full participation.

\section{Method}

Research and development is a research that aims to produce products in the form of developing variations of long jump training. Sugiyono (2008: 407) development research method is a method of research to produce certain products, and test the effectiveness of the products mentioned.

\subsection{Adhesives and research methods}

The method used in this research is development research which includes: product development, testing the effectiveness of products that reach the desired goals. The end result of this research and development activity is to develop a variety of long jump exercises.

\subsection{Data analysis techniques}

In this development research data analysis techniques used are quantitative descriptive analysis techniques with percentages. Each validation instrument variable calculated by the number of percent is then averaged by another variable. Each validator will have a different value. The four validator values which consist of several variables on one model are averaged 
and that is the reference whether the model is used or not. The formula for processing responses or evaluations from experts is calculated using a percentage formula, namely:

$$
\text { Formula : } P=\frac{\text { Amount of Value Obtained }}{\text { Total number }} \times 100 \%
$$

Tables. 1. Percentage Analysis of Validation Results on the Model

\begin{tabular}{lll}
\hline Prosentage & Information & Mean \\
\hline $80 \%-100 \%$ & Valid & Used \\
$60 \%-79 \%$ & Valid enough & Used \\
$50 \%-59 \%$ & less valid & Replaced \\
$<50 \%$ & Invalid & Replaced \\
\hline
\end{tabular}

\section{Result and discussion}

The main text should be written using Times New Roman, 10pt, fully justified. Italics can be used for emphasis and bold typeset should be avoided.

\subsection{Needs analysis}

Based on observations made by researchers, it was found that $90 \%$ of the samples agreed with new variations in long jump learning .

\subsection{Product design}

The products of this study have been contained in videos and manuals for implementing long jump variations.

\subsection{Results of design validation}

After being revised by the long jump trainer and sports academics, the five variations offered are appropriate and feasible to be carried out the next stage

\subsection{Result and small group testing phase}

Strongly encourage authors to use this document for the preparation of the camera-ready. Please follow the instructions closely in order to make the volume look as uniform as possible (Moore and Lopes, 1999). 


\subsection{Result and small group testing phase}

Table 2. Result

\begin{tabular}{|c|c|c|c|c|c|}
\hline \multirow{2}{*}{ No } & \multirow{2}{*}{ Question } & \multicolumn{2}{|c|}{ Results } & \multicolumn{2}{|l|}{$(\%)$} \\
\hline & & Yes & No & Yes & $\mathrm{No}$ \\
\hline 1 & $\begin{array}{l}\text { Are variations on long jump } \\
\text { training developed according to } \\
\text { your expectations? }\end{array}$ & 14 & 1 & 93,33 & 6,66 \\
\hline 2 & $\begin{array}{l}\text { Will the development of } \\
\text { variations in jumping exercises } \\
\text { increase the interest in training / } \\
\text { learning? }\end{array}$ & 13 & 2 & 86,7 & 13,3 \\
\hline 3 & $\begin{array}{l}\text { Are variations on long jump } \\
\text { exercises easy to do? }\end{array}$ & 13 & 2 & 86,7 & 13,3 \\
\hline 4 & $\begin{array}{l}\text { Is the development of a variety of } \\
\text { exciting long jump exercises that } \\
\text { can be made in practice or } \\
\text { learning? }\end{array}$ & 15 & 0 & 100 & 0 \\
\hline 5 & $\begin{array}{l}\text { Whether developing a variety of } \\
\text { long jump exercises can make it } \\
\text { easier for you to master the long } \\
\text { jump technique? }\end{array}$ & 14 & 1 & 93,3 & 6,66 \\
\hline 6 & $\begin{array}{l}\text { Can the development of long } \\
\text { jump training improve the results } \\
\text { of jumps? }\end{array}$ & 12 & 3 & 80 & 20 \\
\hline
\end{tabular}

\section{Conclusion}

This lack of variation in learning makes the level of saturation even higher in the implementation, so that a new variation of training is needed. With a variety of exercises, students / athletes are increasingly excited, motivated in a competitive atmosphere, and variations of the developed exercises are expected to change the culture of students / athletes from those who rely on physical abilities alone, with variations of the developed training can change the training culture that can balance the ability physical with the ability of the mind or reason. 


\section{References}

[1] Harsono.: Penentuan beban latihan, (1998)

[2] Sujoto.: Penentuan beban latihan, (1998)

[3] Soekarman.: Prinsip pulih asal, (1989)

[4] Sugiyono.: Metode penelitian Kuantitatif, kualitatif dan R \& D. Alfabeta, Bandung (2008)

[5] Sujadi.: Penelitian dan Pengembangan atau Research and Development (R\&D) (2003)

[6] Suhardjono.: Penelitian Bidang Pendidikan (1997)

[7] Sukmadinata.: Penelitian dan pengembangan (2002)

[8] Engkos Kosasih.: Olahraga Teknik \& Program latihan (1985)

[9] Aip Syarifuddin dan Muhadi.: Pendidikan Jasmani dan kesehatan, Jakarta:Depdikbud (1992)

[10] Carr, Gerry A.: Atletik (Edisi Terjemahan). PT. Raja Grafindo Persada, Jakarta (2000)

[11] Djumidar.: Dasar-Dasar Atletik. Universitas Terbuka, Jakarta: (2001)

[12] Edy Purnomo \& Dapan.: Dasar-Dasar gerak atletik. Alfamedia jurnal.untan.ac.id jurnal.fkip.uns.ac.id, Yokyakarta. (2011) 